\title{
The Impact of Conservatism Policy on Reporting Quality in Jordanian Banks Sector
}

\author{
Odai Haitham Al Jaloudi \\ Department of Accounting and AIS, Al Balqa Applied University, Al Balqa, Jordan
}

Email address:

odaijaloudi@hotmail.com

\section{To cite this article:}

Odai Haitham Al Jaloudi. The Impact of Conservatism Policy on Reporting Quality in Jordanian Banks Sector. Journal of Finance and Accounting. Vol. 6, No. 3, 2018, pp. 91-95. doi: 10.11648/j.jfa.20180603.12

Received: August 28D, 2018; Accepted: September 10, 2018; Published: October 9, 2018

\begin{abstract}
Reporting quality considered to be a significant factor of the Financial Accounting Standard Board (FASB), while accounting conservatism is a serious constraint that linked to the main criteria of the accounting information. In this study, an investigation of the impact of conservatism policy on the reporting quality of banks in Jordan has been carried out. For this purpose, data is collected for 15 Jordanian banks listed on the official website of the Amman Stock Exchange for a total duration of 10 years from 2008-2017. Initially, it is examined whether the selected banks practice conservatism or not and then the variable is operationalized in terms of a categorical variable having two main categories of conservatism and nonconservatism. Similar the reporting quality is also a qualitative variable that is operationalized as a binary variable using the extent of disclosed information in financial statements as a proxy for reporting quality, like financial reports containing detailed information in the form of notes are considered as providing quality information having a value of 1 and 0 otherwise. The binary logistic regression method is adopted in this study as a quantitative technique for data analysis which expresses the impact of the independent variable on the dependent variable in form of the odds ratio. The study findings show that Jordanian banks most of the time implement conservatism policy and it significantly influences their reporting quality. Moreover, it has been found that Jordanian banks practice accounting conservatism while disclosing their financial information and such conservatism practice has a positive impact on their reporting quality.
\end{abstract}

Keywords: Conservatism Policy, Reporting Quality, Financial Information, Jordanian Banks

\section{Introduction}

Accounting conservatism, the practice of anticipating future losses while ignoring future profits, is practiced by accountants to save themselves and their organizations from future uncertainties that require creating a margin in reported financial information so that uncertainties can be mitigated in future without having much effect on reported incomes or profits [1]. Thus, accounting conservatism is considered as a significant part of organizational financial activities because it is strongly associated with the accounting information leading to investment decision [2]. The increasing impact of conservatism on investment decisions has compelled researchers to investigate its impact on various financial aspects of organizations like their reported income, type of information disclosed in financial reports, and their information quality. Accounting conservatism and its extent being implemented in financial reports has gained researchers attention since last decade, because it influences the disclosure of information in financial reports [3]. As conservatism focuses on anticipating future losses instead of future gains thus considered to be a protector of creditors and stakeholders of organization through its influence on financial indicators of organization like earnings per share, profit, market value etc. [4]. As financial information disclosed by organization is influenced by conservatism then it is considered that it may have an influence on the reporting quality if financial information of the organization because if earnings and profits are not disclosed in their actual form it means the reporting quality of organization is not ensured [5]. Thus, current study investigates the impact of conservatism on reporting quality of banks in Jordan. Although many proxies are used for reporting quality in literature, because no appropriate measurement tool exists so far, thus researchers use their suitable ones. Similarly, current study uses the extent of dislosed information in the form of 
notes as the quality of reporting, because organizations are required to disclose their additional information in the form of notes in their financial reports as well [6]. So, the financial reports of banks having detailed information fall in the category of quality information while not having detailed information fall in the category of non-quality reporting [7].

Current study significantly contributes in literature and practically in knowledge of stakeholders, creditors and other stakeholders that how conservatism influences the reporting quality of banks and whether it exploits the actual financial information of organization. It helps stakeholders identifying the worth of information disclosed in financial reports. Moreover, the examination of conservatism in Jordanian Banks highlights the efficiency of Jordanian banks and the reliability of information disclosed by them. It also facilitates investors in their decision making about making investments in Amman Stock Exchange [8], that whether they should rely on the disclosed information and form their decisions accordingly or not?

\section{Literature Review}

Reporting quality is an essential requirement of Financial Accounting Standard Board (FASB), while accounting conservatism is considered as a serious constraint as it is mainly associated with the major aspects of accounting information; the disclosure and measurement [9]. Implementation of conservatism requires manipulating the actual financial information of the organization like disclosing financial assets lesser than possessed by the organization while reporting enhanced numbers of liabilities and obligations in view of anticipated future losses. It means the actual information is distorted in this manner and reports are based on some exploited numbers [10].

Accounting conservatism provides huge benefits to the organizations and their stakeholders [11], the most prominent one is the tax shield. As obligations and liabilities are disclosed in their enhanced values as compare to assets that are disclosed in smaller numbers than the actual ones thus organizations reap tax shield benefits from such differences [12]. Under this concept, future expenses are recognised in anticipated events while future realised revenues and earnings are delayed being disclosed in financial report [13]. Thus, the transparency of financial information in such reports is clouded by such practices. Such practices are performed in a legal manner by the administration of organization through recognising anticipated expenses while delaying announcements about expected earnings as well as exaggerating the depreciation and other expenses to disclose organizational income in a conservative manner under accepted accounting principles [14].

According to Ref. [15] accounting conservatism incorporates implementing standards that are most determinant about prioritising recognising bad news like losses as compare to good news like profits, as the business outcomes or earnings are more sensitive for bad news as com pare to good news. Conservatism is practiced in two different ways, either amplifying recognition of expected losses; the conditional conservatism or declining the worth of net assets or revealing the least possible value of equity; the unconditional conservatism [16]. But in both case, the information is exploited. Financial Accounting Standards Board (FASB) allows organization to have a possible measurement mistake regarding reducing the actual worth of existing income or assets but not enhancing these, while Ref. [17] indicates that the concept of conservatism incorporates greater tendency of pessimism as compare to optimism while preparing financial reports [18].

Ref. [19] highlights the positive impact of conservatism on enhanced market share value as a driver of conservatism practice in organizations especially in financial sector. Similarly, Ref. [20] state that organizations indulged in an accepted level of conservatism are safer for future uncertainties as conservatism effectively reduces risks of financial failure.

Ref. [21] reported the implementation of accounting conservatism policy by Jordanian organizations while disclosing their financial information. Conservatism is seen as a positive aspect of information disclosure by many researchers as Ref. [22] considered conservatism as a factor enhancing the credibility of financial reporting as well as disclosed information as it takes into accounts the future uncertainties because the influences of financial crisis are not yet over. Moreover, Ref. [23] also indicate that an enhanced level of accounting conservatism leads to a decline in extent of operational risk in organization. conservatism could also be used as a tool for analysing investment risk, so accounting conservatism results in more balance financial information disclosure [24].

Ref. [10] indicates the greater level of accounting conservatism being practiced by Jordanian banks than other sectors of the economy, as well as the impact of firm size prevails in implementing conservatism. Small companies are found to be more conservative in their financial information disclosure than the large companies, while no influence of debt factor is found for the extent of conservatism implemented by organizations. Ref. [9] indicate that accounting conservatism is a tool used to attain a balance between interest of different parties like managers and stakeholders. Moreover, no association is found between ownership structure and conservatism indicating that accounting conservatism is neither limited top private sector nor the public one, rather it may be implemented by any type of organization. Ref. [2] indicate that organizations practicing conservatism, either conditional conservatism or unconditional conservatism, are found to attain contract loans with lower interest rates resulting from conserved financial reports. It is also indicating that implementing conditional conservatism like evaluation of inventory on low cost or net realizable value could facilitate administration attaining its interests.

Ref. [6] indicate that the maturity of financial markets in ways of dealing good and bad information content results in enhanced income response through earning indicators, while 
the sensitivity of income response to bad news is found to be greater than the sensitivity of good news. Ref. [1] used market value as an indicator of the accounting conservatism while depending on the comparative percentage of the market value with the book value at initial stage. While Ref. [6] reported accounting, conservatism used as a tool for governance by organizations having board of directors with strong controls and effective decision making. Moreover, organizations having strong governance reported financial information more conservatively than organizations having weaker governance. Ref. [7] reported the impact of accounting conservatism on earning quality and the disclosed information of the organizations implementing conservatism. Accounting conservatism is also found to be influential for stakeholders' expectations about stock returns. While on the other hand, accounting conservatism is considered as a negative practice of organizations and making investors losing their confidence about information disclosed by the organization.

Ref. [17] documented accounting conservatism being practiced by private sector than the public sector. Moreover, a greater income response is reported for bad news than the good news. Ref. [19] considering accounting conservatism as an earning management practice found a significant negative impact of such practices on stock liquidity and investment portfolios. While Ref. [21] reported a significant positive impact of earning management on return on assets and earnings per share of the organizations. Contrary to the above findings, Ref. [20] found no significant impact of income smoothing, while Ref. [23] on the other hand, found a positive significant impact of income smoothing and earning management on earnings of the organizations. Ref. [22] reported the negative impact of accounting accruals on future stock returns.

\section{Hypothesis}

Based on the above discussion and review of previous literature, current study proposes following hypotheses:

Ho1: Jordanian Banks do not implement accounting conservatism policy.

Ho2: There is no significant influence of accounting conservatism on reporting quality of Jordanian Banks.

\section{Methods}

The population of study is Jordanian Banks listed on Amman stock exchange thus the data collected for financial analysis is collected from official website of Amman stock exchange for a duration of ten years; 2008-2017. 15 banks listed on Amman stock exchange are examined for evaluating the impact of accounting conservatism on reporting quality.

Initially the existence of accounting conservatism in Jordanian banks is tested through following formula, used by [17]:

$$
\begin{aligned}
& \text { Accounting Conservatism } \\
& =\frac{[\text { Net Income }- \text { Net Operating Cash Flow }]}{\text { Net Income }}
\end{aligned}
$$

Less than one (fraction) or negative value for accounting conservatism indicates the existence of accounting conservatism in that period illustrating the conservative accounting policies of the bank in that duration. A negative or less than one value indicates that the net operating cash flows exceeds net income hence exhibiting the reduced net income of the organization. The existence of conservatism is identified in each period then indicating 1 for existence of conservatism and 0 for non-conservatism. Similarly, for accounting quality, the extent of information disclosed by the bank is used as a proxy having two values; 1 for quality reporting in case details are disclosed and 0 for lack of necessary details.

Thus, the quantitative technique for analysis is the binary logistic regression because in current case we have a binary dependent variable; 1 conservatism, 0 non-conservatism and a categorical independent variable; 1 quality reporting and 0 for non-quality reporting. The logit regression expresses impact of independent variable on dependent variable in form of odds ratio. The odds ratios for both categories of independent variable indicate the difference of impact for both categories.

The equation for binary logistic regression is as follows [25]:

$$
\operatorname{Logit}(\mathrm{RQ})=\mathrm{b}_{0}+\mathrm{b}_{1} \mathrm{AC}
$$

Where RQ is the Reporting quality and $\mathrm{AC}$ is the Accounting conservatism, while bo and b1 are the constant and coefficient.

\section{Empirical Testing and Results}

The results for quantitative analysis using SPSS version 25

\begin{tabular}{|c|c|c|c|c|c|c|}
\hline \multicolumn{3}{|c|}{ Logistic regression } & \multicolumn{4}{|c|}{ Number of obs $=150$} \\
\hline & & & \multicolumn{4}{|c|}{$L R \operatorname{chi} 2(1)=3.11$} \\
\hline & & & \multicolumn{4}{|c|}{ Prob $>$ chi $2=0.0761$} \\
\hline \multicolumn{3}{|c|}{ Log likelihood $=-108.90213$} & \multicolumn{4}{|c|}{ Pseudo R2 = 0.0128 } \\
\hline RQ & Coef. & Std. Err. & $\mathbf{Z}$ & $\mathbf{P}>|\mathbf{z}|$ & {$[95 \%$ Con } & \\
\hline $\mathrm{AC}$ & .5827732 & .3514392 & 1.73 & 0.073 & -.0754072 & 1.271972 \\
\hline intercept & -1.470862 & .2689545 & -5.27 & 0.000 & -1.997994 & -.9437088 \\
\hline
\end{tabular}
can be illustrated in the following tables:

Table 1. Results of Logistic Regression. 
The above table indicates the significant impact of accounting conservatism on reporting quality indicated by the $p$ value of the test, but the difference of the impact of non-conservatism and conservatism is indicated by their odds ratio.

The cross tab for both variables is as follows:

Table 2. Cross Tab of RQ (Reporting Quality) and AC (AC; Accounting Conservatism, NAC; Non-accounting conservatism).

\begin{tabular}{llll}
\hline \multirow{2}{*}{$\mathbf{R Q}$} & $\mathbf{A C}$ & & \multirow{2}{*}{ Total } \\
\cline { 2 - 4 } & $\mathbf{A C}$ & NAC & \\
\hline 0 & 15 & 37 & 52 \\
1 & 88 & 10 & 98 \\
Total & 103 & 47 & 150 \\
\hline
\end{tabular}

The above table indicates the cross tab of dependent variable and categories of independent variable, while the odds ratio is illustrated in table 3 .

Table 3. Results for Odds Ratio.

\begin{tabular}{|c|c|c|c|c|c|c|}
\hline \multirow{3}{*}{\multicolumn{2}{|c|}{ Logistic regressio }} & & \multicolumn{4}{|c|}{ Number of obs $=150$} \\
\hline & & & \multicolumn{4}{|c|}{$L R$ chi2 $(1)=3.11$} \\
\hline & & & \multicolumn{4}{|c|}{ Prob $>$ chi $2=0.0761$} \\
\hline \multicolumn{3}{|c|}{ Log likelihood $=-108.90213$} & \multicolumn{4}{|c|}{ Pseudo R2 = 0.0128 } \\
\hline RQ & $\begin{array}{l}\text { Odds } \\
\text { Ratio }\end{array}$ & Std. Err. & $\mathbf{Z}$ & $\mathbf{P}>|\mathbf{z}|$ & $\begin{array}{l}\text { [95\% Conf } \\
\text { Interval] }\end{array}$ & \\
\hline $\mathrm{AC}$ & 1.586013 & .3514392 & 1.73 & 0.073 & .973072 & 2.372872 \\
\hline
\end{tabular}

The odds ratio indicates the impact of different categories of independent variable on both levels of dependent variable. The value of odds ratio greater than 1 indicates the greater impact of level taken as 1 i.e. accounting conservatism in this case, as compare to the other taken as 0 [26] i.e. nonconservatism in this case. So, the value of odds ratio 1.586013 in the above table indicate that the odds ratio for accounting conservatism is almost $59 \%$ greater than the odds ratio of non-conservatism that indicates that accounting conservatism has greater influence on reporting quality of financial information of Jordanian Banks.

\section{Discussion}

As the impact of accounting conservatism is being tested on reporting quality of Jordanian banks, the results indicate that Jordanian banks most of the time implement conservatism policy and it significantly influences their reporting quality. Moreover, the positive coefficients and their significant values indicate that accounting conservatism has positive impact on the reporting quality of banks in Jordan. As accounting conservatism is most of the time considered as a positive practice for financial well being of organizations and their stake holders so Jordanian banks should implement such practices to gain positive results. Moreover, the anticipation of future losses or expenses may make organizational stakeholders cautious about their future actions and decisions and in this way, they would be able to make effective and healthy decisions that will be in the best interest of their organization. as Jordan is among one of the emerging economies, and such economies are mostly prone to economic and other market uncertainties, so the anticipation of future losses and inclusion of such anticipation in financial information is a positive activity that may mitigate the impacts of risks in future. Moreover, when organizations are already disclosing their anticipated losses and expenses they can attract more investors due to the enhanced credibility of their information. Increased financial and other market distresses across globe has enhanced the importance of such practices for organizations, because organizations are not only required to safe their survival in the market but due to the increased demands of market they are also require attracting more and more investors. Investors are always attracted towards organizations, whom they found to be more reliable and disclosing more reliable information for their future decisions. Thus, implementation of accounting conservatism is a positive aspect of Jordanian banks, moreover its positive impact on reporting quality of banks makes it more significant for all stakeholders including investors.

\section{Conclusion}

Accounting conservatism, due to its focus on disclosing more information about anticipated losses and expenses while ignoring anticipated revenues or income, has controversial opinions about its implementation while disclosing financial information of the organization. some think of it as the distortion of actual information while disclosing exploited information, while on the other hand, others think of it as a positive practice by accountants. Favouring the implementation of accounting conservatism, it is argued that organizations that implement accounting conservatism are good in their information disclosure because they disclose even about their future losses, it enhances the credibility of their information as compare to the ones not practicing it. Current study also investigated the impact of accounting conservatism on reporting quality of Jordanian banks. Investigating the data collected for 15 listed banks on Amman stock exchange, it is found that Jordanian banks practice accounting conservatism while disclosing their financial information and such conservatism practice has a positive impact on their reporting quality. As the organization is disclosing about its anticipated loss or expense, it facilitates investors to have efficient decision making about such organizations. but despite anticipated future losses or expenses, such organizations implementing accounting conservatism are more attractive for investors as they find these more reliable than the others who do not disclose their such information.

\section{Limitations and Future Implementations}

Current study is limited for investigating whether there is a positive or negative impact of accounting conservatism on reporting quality of Jordanian banks, while the extent of such 
impact is not tested in this study. So further research could be conducted for this. Moreover, such impact can also be impacted for other financial and non-financial organizations in other emerging economies as well.

\section{References}

[1] Najjar J (2014) Measuring the level of accounting conservatism in the financial statements and its effect on the market values of the shares: Applied study on the Palestine companies. Journal of Plqa Research and Studies17: 177-224.

[2] Ball R, Kothari S (2007) Econometrics of the Basu asymmetric timeliness coefficient and accounting conservation. Social Science Research Network.

[3] Ball R, Robin A, Sadka G (2008) Is financial reporting shaped by debt markets or by equity markets? An international study of timeliness and conservatism. Review of Accounting Studies 13: 168-205.

[4] Sana, N. M. (2016) The Effect of Accounting Conservatism on Financial Performance Indicators in the Jordanian Insurance Companies. Journal of Banking and Commerce. 2, 1: 1-16.

[5] Ball R, Shivakumar L (2005) Earnings quality in UK private firms: comparative loss recognition timeliness. Journal of Accounting and Economics 39: 83-128.

[6] Jomely A (2014) Accounting conservatism and its effect on the prediction of financial failure in Jordanian industrial companies: Analytical study. Master Theses, Zarqa private University, Jordan.

[7] Eqbal, Omar, legdah, Mamon (2014) The effect of financial crises on the support of the accounting conservatism policy: A study in Jordanian industrial companies. Najah University Journal for Research 8: 895-920.

[8] Amman Stock Exchange (2018) Retrieved from: https://www.ase.com.jo/en/equities [Accessed August 5, 2018].

[9] Wang RZ (2013) Operating risk and accounting conservatism: an empirical study. The International Journal of Business and Financial Research 7: 12-29.

[10] Hanan M (2012) The effect of the accounting conservatism in improving earnings quality of financial reporting: A Case Study of Jordanian industrial companies. Aldrasat Administrative Sciences 38: 33-55.

[11] Hendriksen, Eldon S, Richard D (1982) Accounting Theory. Irwin. Inc.

[12] Cullinana CP, Wangb F, Wangb P, Zhangb J (2012) Owner ship structure and accounting conservatism in China. Journal of International Accounting, Auditing.
[13] Latridis G (2011) Accounting disclosures, accounting quality and conditional and unconditional conservatism. International Review of Financial Analysis 20: 88-102.

[14] Khair T (2008) New perspective of accounting conservatism: Applied study in Egyptian companies. Scientific Journal for Commercial and Financing 5: 55-77.

[15] Lara J, Torres J, Veira P (2007) Board of directors' Characteristics and conditional accounting conservatism: Spanish Evidence. European Accounting Review 16: 705-727.

[16] Penman SH, Zhang XJ (2002) Accounting conservatism, the quality of earnings, and stock returns. The Accounting Review 77: 237-264.

[17] Givoly D, Hayn C (2000) The changing time-series properties of earnings, cash flows and accruals: Has financial reporting become more conservative. Journal of Accounting and Economics 29: 287-320.

[18] Daneshmand BJ, Moeinaddin M, Dehnavi HD (2014) The Effect of Earnings Management on The Stock Liquidity. Interdisciplinary Journal of Contemporary Research in Business 5: 73-81.

[19] Chiraz D, Jaboui A (2013) Earning Management and Performance of French IPO Companies. Journal of Accounting and Taxation 5: 1-14.

[20] Hejazi R, Zinat A, Mehdi S, Fahime E (2011) The Impact of Earnings Quality and Income Smoothing on the Performance of Companies Listed in Tehran Stock Exchange. International Journal of Business and Social Science 17: 193-197.

[21] Abbas A, Nikbakht Z (2009) Income Smoothing Real Earnings Management and Long-Run Stock Returns. Business Intelligence Journal 3: 55-73.

[22] Chan, K., Chan, L. K. C., Jegadeesh, N., Lakonishok, J. (2006) Earnings Quality and Stock Returns. Journal of Business 79: 1041-1082.

[23] Gill, A, Bigger, N., Mathur, N. (2010) The relationship between working capital management and profitability: Evidence from the United States. Business and Economics Journal 10:1-9.

[24] Kieso, D., Weygand, J.and Warfield, T (2014) Intermediate accounting (15th edn.). Wiley and Sons, New Jersey.

[25] Harrell F E (2015) Binary Logistic Regression. In: Regression Modelling Strategies. Springer Series in Statistics. Springer, Cham. Pp. 219-274.

[26] Szumilas M (2010) Explaining Odds Ratio. Journal of the Canadian Academy of Child Adolescent Psychiatry. 19:227229. 